\title{
Characterisation, Authority and Ideology in Ngũgĩ’s Devil on the Cross
}

\author{
Léonard A. Koussouhon ${ }^{1}$ \\ Yémalo C. Amoussou² \\ FLASH/UAC, Republic of Benin \\ 'e-mail: koussouhon@yahoo.com; ${ }^{2} e-m a i l:$ Cayemal@yahoo.fr
}

\section{Doi:10.5901/mjss.2015.v6n4s3p279}

\section{Abstract}

This paper analyses the direct characterisation passages in Ngũgĩ wa Thiong'o's novel Devil on the Cross (1982). It identifies the different uses of modality, an indicator of narratorial authority, in order to show how the predominant use of modalisation has helped the narrators to mark not only their externality to what they depict, but also their subjectivity or lack of confidence with regard to their interpretations of capitalist characters' actions. Yet, with a near exclusive use of modulation with regard to the depiction of proletarian personages, these narrators have somehow given clues about their closeness to and admiration for them. All this has helped to deduce their ideological orientation regarding the two groups of characters.

Keywords: characterisation, authority/modality, modulation, modalisation, ideology.

\section{Introduction}

It is a widely held view in systemic functional linguistics that language expresses three basic functions/meanings (experiential, interpersonal and textual) and those meanings are influenced by the situational, cultural and ideological contexts in which they are exchanged (Halliday, 1985a, Fowler, 1986; Eggins, 1994/2004; Halliday \& Matthiessen 2004). This means that the interpersonal relationship between the speaker/narrator and the speech subject will influence his/her rendering of the experience/perception of the latter, as will his/her belief about the spoken about. The fact is one does not use language in the same way to talk to/about one's friends as to do so about one's enemies. As such, the analysis of a speaker's/narrator's discourse tenor will reveal information as to whether the speaker and the spoken about are close friends, distant acquaintances or poles-apart antagonists.

This article aims at showing the impact of ideology on authority/modality in the delineation of the two major groups of characters in Ngũgĩ's Devil on the Cross (1982). As it has become a widely accepted principle in systemic functional linguistics that a linguistics-oriented analysis of discourse, including literature, is both an act of description and interpretation (Jakobson, 1960; Pearce, 1977; Halliday, 1985a; Hill, 1987; Brumfit \& Carter,1991, etc), the methodology used here will involve the identification and analysis of relevant linguistic structures and features as related to characterisation with a view to revealing their different meanings, then the interpretation(s) of those meanings, drawing on context (situational, cultural and ideological), for a better appreciation of them. As Halliday, in his preface to Cummings \& Simmons (1983), puts it, "the more immediate goal [of a linguistc-stylistic inquiry] is to show how and why a text means what it does" ( $(\mathrm{x})$. This implies the combination of both a quantitative/descriptive method and a qualitative/interpretative one.

Drawing on that approach, the paper identifies and analyses the narratorial modality in about 30 characterisation passages to reveal how the main narrator and the minor ones resort to different modal choices to express their distance/proximity and confidence/hesitancy about the characters depicted. Though some items are explicitly derogatorily used (e.g.: capitalism=robbery/theft/loyalism; capitalists=robbers/thieves/parasites/loyalists; proletarians=patriots/ producers), the analysis goes beyond the explicit to point out the implicit impact of modality/authority on the two ideological lines drawn in the novel. Before the analysis (3.1 \& 3.2) and the interpretation resulting from it (3.3), the conceptual/theoretical framework is briefly reviewed (section 2).

\section{Theoretical Underpinning}

The term "characterisation" is used in linguistics and literature to refer to the conception and presentation of characters/personages in a literary work. In other words, it refers to the linguistic construction of fictitious people, their 
painting, their naming, and their enrolment in a work of fiction. It is thus a literary discourse device exploited by a writer either textually through the characters' direct descriptions, external appearance and environment or their speeches and actions, or intertextually through naming and analogous character-indicators.

As for the term "authority," it refers to the degree of certainty/confidence/commitment with which a speaker/writer/narrator states whatever is expressed through language. As such, there is a close connection between the term "authority" and "modality". For Fowler (1986), the term "modality" refers to "the grammar of explicit comment, the means by which people express their degree of commitment to the truth of the propositions they utter, and their views on the desirability or otherwise of the states of affairs referred to" (p.131). From this definition, it ensues that the grammar of modality has two components: modalisation and modulation. While the former is the expression of the speaker's/writer's judgement about certainty, likelihood, frequency, and operates through modal locutions like "can, could, may, might, , I think, it's likely, it's possible, it's probable...etc" (Eggins, 1994/2004); the latter is about obligation and inclination, through modals like "must, should, need, ought to, have to, shall, will, won't, cannot, l'm sure, etc" (Halliday, 1985a; Fowler, 1986; Eggins, 1994/2004).

Fowler (1986), drawing on Uspensky (1973), further contends that the use of words of "estrangement", comparisons (similes and metaphors) is a good indicator of narratorial externality and subjectivity in fiction, thus, of modalisation:

Externality in relation to characters emerges when the narrator's modal activity includes what Uspensky calls words of estrangement: words such as 'apparently' 'evidently' 'perhaps' 'as if', 'it seemed', ...etc., as well as metaphors and comparisons. These expressions pretend that the author - or often, one character observing another - does not have access to the feelings or thoughts of the characters. They emphasize an act of interpretation, an attempt to reconstruct the psychology of characters by reference to signs that can be gleaned by external observation (p.142).

He further argues that the intense use of modulators (must, will, shall, ought to, need, certainly, I'm sure, etc) indicates confidence and omniscience while that of modalisers (may, might, perhaps, could, seem, as if, as though, apparently, seemed as if, looked as if, appeared as if, etc) marks subjectivity or caution or partiality (Fowler, 1986, Halliday, 1985, Eggins, 1994). As a result, Brown (1980), in McCornell-Ginet et al. (1980: 122) uses the word 'strengtheners' to refer to the first group and 'weakeners' for the second. That is why, in this study, the terms "estranger,' 'modaliser,' and 'weakener,' are synonymously used and so are 'modulator,' and 'strengthener'. As such, a study of modality is a good means of showing the narrator's authority and intrusion into literary discourse.

As for the word "ideology," it refers to the set of beliefs and assumptions on the basis of which a speaker judges what is being spoken about or marks his/her idiosyncratic distance to it. Logically, our belief about someone/something can significantly influence or determine our attitude to them/it; that is the tenor relationship (power/hierarchy; solidarity, friendship, enmity, hostility, desirability, undesirability, hospitality, commitment, etc) between the speaker and the subject of his/her speech. Thus, there can be a close complementarity between "authority/modality" and "ideology" and both can influence a narrator's/writer's portrayal of a character or a class of characters (Eggins, 1994/2004, Halliday, 1985; Koussouhon and Amoussou, 2013; Amoussou, 2013). In general, we do not speak in the same way about a person we feel for as about one we don't feel for. The next section explores the impact of authority/modality on characterisation and how it helps to draw the narrator's/writer's ideological position to the classes of characters painted in the novel.

\section{Analysis of Authority, Characterisation and Ideology in Devil on the Cross}

\subsection{Authority and Characterisation of the Capitalists/Robbers/Loyalists.}

The first character from this group to be introduced to the reader is the unnamed master of ceremonies, who is described in these terms:

(1) He had a well-fed body; his cheeks were round, like two melons; his eyes were big and red, like two plums; his neck was huge, like the stem of a baobab tree. His stomach was only slightly larger than his neck. He had two golden teeth in his lower jaw, and when talking, he opened his lips wide so that the gold teeth could be seen. He had on a silk suit which shone in the light, changing colour according to the intensity of the light and the angle of the beam. (p.87).

The modal activity in this description can be summed into 03 similes, in which the MC's cheeks are likened to "melons", his eyes to "plums" and his neck to "the stem of a baobab tree." All these items - melons, plums, baobab stem - denote fleshiness and fatness. There is also 01 comparative of equality in which the size of his neck is equalised with 
that of his belly, which gives the picture of a disproportionate person. There is $\mathbf{0 1}$ projected clause introduced by the purpose-expressing conjunctive locution "so that", which clearly shows the show-off character of the MC.

The portrayal of the 7 foreign capitalists is also revealing both modally and ideologically:

(2) The seat taken by the leader of the foreign delegation was a little higher than the others. On his right sat three foreigners, and on his left sat the other three. As she stared at them, Waringa noted that their skins were indeed red, like that of pigs or like the skin of a black person who has been scalded with boiling water or who has burned himself with acid creams. Even the hair on their arms and necks stood out stiff and straight like the bristles of an aging hog. The hair on their heads was brownish, the colour of moleskin. It was long, and it fell on the shoulders as if it had never been shaved off or cut off since birth. On their heads, they wore hats like crowns. Each crown was decorated with seven metal objects shaped like horns, which gleamed so brightly that they almost blinded the eyes. All the crowns looked alike, but the leader's was a little larger than the others. The tips of the horns were twisted into the initial of the country that each delegate came from.

There were differences in the suits they wore. The one worn by the leader was made of dollars, the Englishman's of pounds, the German's of Deutschmarks, the Frenchman's of francs, the Italian's of lire, the Scandinavian's of kroner, and the Japanese delegate's of yen. Each suit was decorated with several badges, like those worn by scouts. The badges were made of metal, and like neon advertisements, they flashed on and off, illuminating the words that were inscribed on them.... (p.91).

This is how the narrator introduces the members of the G-7 at the time (US, Japan, Germany, UK, France, Italy, and Canada.) In the description above, the sitting position, the height of the seat and the size of the hat worn by the American delegate are all indicative of the centrality and paramouncy of his country in both the G-7 and the capitalist system. This paramouncy is also signalled by the use of two comparatives of superiority (a little higher, a little larger) to show the relative power of the US over the others. In addition the currency of each member country has been used to mark its delegate's identity. The modal activity is signalled by $\mathbf{0 7}$ similes, $\mathbf{0 3}$ of which liken a white man to "a pig", or "a hog" or "a burnt or scalded black man." The other 04 create these associations "hats=crowns", "hat tops=horns," "delegate's badges=scout badges," and "badges=advertisements". There is $\mathbf{0 1}$ nominalised simile, the noun phrase "the colour of a moleskin", which can be rephrased into "as brown as a moleskin," likens the white man's hair colour to a "moleskin's". Finally there is $\mathbf{0 1}$ estranger "as if', which shows not only the externality of the observer but also the speculative/uncertain nature of the observation. The number " 7 ", i.e., the number of horns on each delegate's hat, is very significant here not only for it represents the number of countries within the G-7 at that time, but it also creates a parallel between this Group and the Devil as depicted below:

(3) She saw first the darkness, carved open at one side to reveal a Cross, which hung in the air. Then she saw a crowd of people dressed in rags walking in the light, propelling the Devil towards the Cross. The Devil was clad in a silk suit, and he carried a walking stick shaped like a folded umbrella. On his head there were seven horns, seven trumpets for sounding infernal hymns of praise and glory. The Devil had two mouths, one on his forehead and the other at the back of his head. His belly was sagged, as if it were going to give birth to all the evils of the world. His skin was red, like that of a pig. Near the Cross he began to tremble and turned his eyes towards the darkness, as if his eyes were being seared by the light. He moaned, beseeching the people not to crucify him, swearing that he and his followers would never again build Hell for the people on Earth.

But the people cried in unison: 'Now we know the secrets of all the robes that disguise your cunning. You commit murder, then you don your robes of pity and you go to wipe the tears from the faces of orphans and widows. You steal food from people's stores at midnight, then at dawn you visit the victims wearing your robes of charity and you offer them a calabash filled with the grain that you have stolen. You encourage insciviousness solely to gratify your own appetites, then you put on robes of righteousness and urge men to repent, to follow you so that you show them the paths of purity. You seize men's wealth, then you dress in robes of friendship and instruct them to join in the pursuit of the villain who has robbed them.' And there and then the people crucified the Devil on the Cross, and they went away singing songs of victory.

After three days, there came others dressed in suits and ties, who, keeping close to the wall of darkness, lifted the Devil down from the Cross. And they knelt down before him, and they prayed to him in loud voices, beseeching him to give them a portion of his robes of cunning. And their bellies began to swell, and they stood up, and they walked towards Wariinga, laughing at her, stroking their large bellies, which had now inherited all the evils of the world...(pp.13-14)

As can be seen in the first paragraph of the quote, the Devil's hat has 7 horns, just like those of the delegates, his skin is likened to that of a pig, just like the delegates', and his belly compares well with that of most of the competitors or robbers, as will be discussed shortly. Moreover, the Devil is dressed in silk suit, like most of the competitors/robbers, and the European judge, who has tried Wangari, a female character, for vagrancy, is described in terms similar to those of the 
Devil and the delegates (the pig-skin imagery, the lizard-like nose): (4) "The judge was a European, with a skin that was red like a pig's. His nose was peeling, like a lizard's body. He wore glasses with big arms" (p.43). All these similarities do lead to the impression that the Devil in question is the embodiment or personification of capitalism or imperialism represented by the G-7 (the Group of the Seven most Industrialised countries in the world at the time the story was written; with the admission of Russia into the Group in 1997, it became the G-8.) Overall, the following equation can be established: Capitalism=G-7= Devil=Robbery=Theft. The second paragraph of quote (3) clearly depicts the double guises under which this system of robbery functions: murderer-empathiser/murder-pity, thief-donor/theft-charity, inscivious-pure, robber-policeman, etc. The crucifixion of the Devil by men in rags is synonymous with the destruction of capitalism or colonialism by Kenyan peasants, workers and Mau Mau militants and its resurrection three days later by the suit-wearing men becomes the rebirth of colonialism, that is, neo-colonialism, by the country's political and economic elite. This gives the idea of ideological cyclicality which calls for revolutionary rebirth, as the resurrection of the Devil is responded with by the return "to the forests and to the mountains" (p.239), a new Mau Mau insurgency. The modal activity in quote (3) above can be summed up into: $\mathbf{0 2}$ similes (like, like) and $\mathbf{0 2}$ modalisers (as if, as if).

There even is a substitution of Christ for the Devil. Indeed, the paintings of Christ and the Devil on the walls of the Church of the Holy Rosary and their reverse experience in the heroine's mind can be said to have strong ideological clues:

(5) What Wariinga tried hard to avoid- though her eyes kept straying in that direction - was looking at the pictures on the walls and windows of Church of the Holy Rosary. Many of the pictures showed Jesus in the arms of the Virgin Mary or on the Cross. But others depicted the Devil, with two cowlike horns and a tail like a monkey's, raising one leg in a dance of evil, while his angels, armed with burning pitchforks, turned human beings on a bonfire. The Virgin Mary, Jesus and God's angels were white, like Europeans, but the Devil and his angels were black. At night, Wariinga would have a recurrent nightmare. Instead of Jesus on the Cross, she would see the Devil, with the skin as white as that of a very fat European she once saw near the Rift Valley Sports Club, being crucified by people in tattered clothes -like the ones she used to see in Bondeni -and after three days, when he was in the throes of death, he would be taken down from the Cross by black people in suits and ties, and thus restored to life, he would mock Wariinga (p.139).

In this quote, as is traditionally painted in European literature, God, Christ, Mary, God's Angels, and Europeans are white, pure and positive while the Devil, its Angels and Africans are black, impure or bad and negative. But in the heroine's nightmare, the Devil is as white as a European, is crucified by black people in rags and resurrected by other black people in suits and ties. This means that the Kenyans elite are almost entirely responsible for the rebirth of colonialism in the country. The modal activity here includes 03 similes (like, like, like) and 01 comparative of equality (as white as).

The characterisation of the Kenyan capitalists/robbers/thieves has the same modal characteristics as the one of the Devil and its representatives. This is the physical description of the first competitor or robber:

(6) "The suit that this competitor was wearing was the kind that had been baptized Napier-Grass-Son-of-Trembling. It showed no sign of ever having been pressed. He was tall and lanky. But his eyes were big; they were like two electric bulbs hanging from a tall eucalyptus tree. His arms were long, and he swung them this way and that way, as if he did not know what to do with them -whether to put them in his pockets, to hold them stiff, like a soldier standing to attention, or to fold them, like a man in defiant mood ...And there and then, Ndaaya, bending low on the platform, Ndaaya wa Kahuria began swinging his arms this way and that, as if he could see real chickens in front of him, ......(p.94).

The narratorial modality here is expressed through 03 similes (eyes like two electric tubes; arms like a soldier standing to attention, arms like a man in defiant mood); and 02 estrangers (as if, as if...). The next robber to compete, a lukewarm court clerk during the emergency, son of a loyalist become a big landowner and a billionaire, Gitutu wa Gataanguru by his traditional name and Rottenborough Groundflesh Shitland Narrow Islamus Joint Stock Brown by his European/Christian name, is described as follows:

(7) Gitutu had a belly that protruded so far that it would have touched the ground had it not been supported by the braces that held up his trousers. It seemed as if his belly had absorbed all his limbs and all the other organs of his body. Gitutu had no neck -at least, his neck was not visible. His arms and legs were short stumps. His head had shrunk to the size of a fist. That day Gitutu wa Gataanguru was sporting a dark suit and a white shirt with frills. A black bow tie, which looked as if it had been stuck to his chin, stood where his neck should have been. His walking stick was decorated with pure gold. While he talked, Gitutu stroked the side of his belly with his left hand and swung his walking stick with his right hand. He panted as he talked, like a person carrying a heavy load. (p.99). 
A look at the European name, with morphemes like "shitland", "groundflesh", and "rottenborough", is enough to grasp the denotation of distastefulness it conveys. The physical description, with phrases such as "belly touching the ground", "belly that protruded so far", "belly had absorbed his limbs", " no visible neck", "head shrunk to the size of a fist" , gives the picture of a man reduced to his belly as all other parts of his body are over dominated by that one. The narratorial modality here is signalled by $\mathbf{0 2}$ double modalisers "seemed as if, looked as if", $\mathbf{0 2}$ metaphors "arms and legs= short stumps; head = fist" and 01 simile "like a person carrying a heavy load". These modal locutions, just like the others identified earlier and to be identified later, give the impression of a subjective observer watching and interpreting the character's actions speculatively from outside. The narratorial comment after the character's performance is also modalised with an estranger "as if", as can be seen in (8): "By the time Gitutu wa Gataanguru had finished his testimony, he was panting with fatigue. Drops of sweat fell to the floor. His protruding belly was trembling as if it wanted to break loose and fall to the ground" (p.108).

The other robber or thief to be portrayed, a former Primary School teacher become school owner, then County Councillor and politician, is Kihaahu wa Gatheeca by his Kikuyu name, and Lord Gabriel Bloodwell-Stuart-Jones for foreign name, is described like this:

(9) Kihaahu was a tall, slim fellow: he had long legs, long arms, long fingers, a long neck and a long mouth. His mouth was shaped like the beak of the kingstock: long, thin and sharp. His chin, his face, his head formed a cone. Everything about him indicated leanness and sharp cunning. That day, Kihaahu was dressed in black-and-grey stripped trousers, a black tailcoat, a white shirt and a black tie. Standing on the platform, he looked like a 6-feet praying mantis or mosquito (p.108).

The use of modality is similar here again: there are $\mathbf{0 3}$ similes (mouth... like the beak of the kingstock; he looked like a 6-feet praying mantis; he looked like a mosquito), and 01 metaphor (head=a cone). As it appears, there is a resort to animal imagery (beak of a king-stork, praying mantis, mosquito) in the painting of this character. The kingstock is a very tall long-legged bird with a heavy bill; known for its rigid stance and as a tyrant flycatcher; the mantis is a slender predatory insect waiting motionless for prey with its forelegs folded like hands in prayer; and a mosquito is known for bloodsucking and causing diseases. Similarly, the description of Nditika wa Nguunji, a former loyalist, become a wheelerdealer and insider-dealer, conveys a similar sense of animalisation or objectification:

(10) Nditika wa Nguunji was very fat. His head was huge, like a mountain. His belly hung over his belt, big and arrogant. His eyes were the size of two large electric bulbs, and it looked as if they had been placed on his face by a Creator impatient to get on with another job. His hair was parted in the middle, so that the hair on either side of the parting looked like two ridges facing each other on either side of the tarmac road. He had on a black suit. The jacket had tails cut in the shape of the wings of the big green blue flies that are normally found in pit latrines or among rotting rubbish. His shirt had frills all down the front. He was wearing a black bow tie. His eyes rolled in time with his words. His hands rested on his stomach and patted it gently as if beseeching it not to stick out towards the people with such arrogance (p.176).

In this description, there are $\mathbf{0 2}$ modalisers/estrangers 'it looked as if, as if', 01 simile (looked like two ridges), and 01 nominalised simile; the noun phrase "the size of two electric bulbs" is rewritable into "as big as two electric bulbs", which compares the man's eyes to two electric bulbs. In addition, lexical items like "pit latrines", "rotting rubbish," and "big green blue flies" clearly give a denotation of putrefaction associated with the character being thus portrayed. The similar applies to the next robber painted. This description of Kĩmeedeeri wa Kanyuanjii, a loyalist, a former District Officer, now a Permanent Secretary, a big landlord and billionaire, is given by the Devil:

(11) You should be there to see Kimeedeeri wa Kanyuanjii. His mouth is shaped like the beak of the red-billed oxpecker, the tick bird. His cheeks are as smooth as a new-born baby's. His legs are huge and shapeless, like giant banana stems or (like) the legs of someone who is suffering from elephantiasis. But his disease is simply grossness that comes from over-eating. His neck is formed from rolls of fat, like the skin of the hairy maggot. But this astonishing body, these legs and neck, have been completely covered by a white suit and a bow tie..." (pp.186-7)

Narratorial modality here operates through: $\mathbf{0 4}$ similes (mouth like the beak of the red-billed ox-pecker; neck like the skin of a hairy maggot; legs like giants banana stems; legs like those of someone suffering from elephantiasis;), 01 comparative of equality, which is also a simile (mouth as smooth as a new born baby's). As can be seen the same animal imagery (ox-pecker, maggot) or of disproportion or putrefaction (huge banana stems, elephantiasis) is resorted to here. Interestingly, Gatuiria's short description of the same character does dovetail with that of the Devi above, as he 
says: (12) "Kimeedeeri wa Kanyuanjii was certainly there, but it was difficult to tell whether he was a human being or a fat, hairy worm with a beak" (p.196). Another robber is named Fathog Macura wa Kimeengemeenge (the bolded name means "Gros Cochon" in French), is described thus: (13) "His belly was so huge that it almost bulged over his knees" (p.122). Finally, Superintendent Gakano is shown in this light: (14) "Gakano, springing to attention, saluted and started offering apologies and begging for forgiveness in a trembling voice. He spoke as if fear had penetrated his flesh and bones and (as if) he did not understand the use of the comma or full stop" (p.197). This description contains 02 estrangers (as if, as if), which marks the observer's externality to that which is observed and the speculative nature of his/her observation.

Overall, almost all the followers of the Devil/capitalism (G-7 members and loyalists) are painted through animal and object imagery by means of comparison (simile and metaphor) and other modalisers/estrangers/weakeners. This means that the observer sees capitalism and loyalism in terms of animalism/animosity/devilishness/ugliness, while patriotism is viewed in terms of humanism/beauty, as section (3.2.) will shortly show. Indeed, there is some image/symbol of parasitism and uglification associated with capitalism, as can be seen in this comment by a character, softened by a modalised narratorial comment: (15) "fleas, jiggers, bedbugs...are there more of those in Ilmorog's slums than the human parasites we have left behind in the cave?" Gatuiria asked slowly, as if he were talking to himself" (p.131). Similarly, the heroine sees Gatuiria's father, a business tycoon who has spoilt her life and whom she has just gunned down out of revenge, as a multidimensional parasite: (16) "There kneels a jigger, a louse, a weevil, a flea, a bedbug! He is mistletoe, a parasite that lives on the trees of other people's lives!" (p.254). This may be the tour de force of the writer's indirect use of animal images through characters' speeches to criticise, not only the unproductiveness of capitalism, but also of its parasitism. Indeed, the heroine has resorted to a 7-degree gradualist metaphor to judge the capitalists, represented by Githahi: jigger, louse, weevil, flea, bedbug, mistletoe, and parasite. In this judgement, there also are two exclamations $(!, !)$, which, in this context, express the speaker's degree of anger and indignation towards her oppressor. Moreover, the narrator's comments on her actions during this judgement give her a lot of authority over her destroyer and they can hardly be passed out without ideological coloration. Indeed, those comments contain $\mathbf{0 3}$ positively-oriented similes in which the lady is likened to a judge, a symbol of authority:

(17) "Waringa looked at him like a judge at an unrepentant prisoner who is pleading for mercy" (p.249)

(18) "Wariinga commanded, with the voice of a judge" (p.253).

(19) "She began to speak like a people's judge about to deliver his judgement" (p.253).

In (20) below, stink and putrefaction cognates like 'smelled, the fart of a badger, rotten beans, over-ripe bananas, nausea' help to hint to the collective rottenness of the robbers.

(20) "Wariinga could not bear the scene in the cave any longer. The talk sat heavily on her mind, like a log of wood. The breath of the speakers smelled worse than the fart of a badger or of someone who has gorged himself on rotten beans or over-ripe bananas. Nausea swept over her. She excused herself to Gatuiria and lied that she was going out to answer a call of nature. But what she wanted most was a breath of clean, fresh air...She sat on the grass and leaned against a black wattle tree, breathing a long sigh as if the load were being lifted from her heart. (p.182)

Moreover, while the negative comparative 'worse than' points to the character's negative judgement and indignation at the foul breath of the robbers, the modalisers 'like, as if denote the subjectivity of the narrator's interpretation of her actions.

\subsection{Authority and Characterisation of the Proletarians and Patriots.}

While the capitalists are distastefully or animalistically painted, it can be noticed that the characterisation of the patriots (Warīnga, a worker, a mechanical engineer; Mūturi, the worker-delegate; Wangari, the peasant woman and former Mau Mau; Warīnga's mother, a former Mau Mau-detainee; the unnamed students' leader, etc) is much more admirable both lexically and modally. Let us consider these three depictions of the heroine Wariinga:

(21) Wariinga was convinced that her appearance was the root cause of all her problems. Whenever she looked at herself in the mirror she thought herself very ugly. What she hated most was her blackness, so she would disfigure her body with skin-lightening creams like Ambi and Snowfire, forgetting the saying: That which is born black will never be white. Now her body was covered with light and dark spots like the guineafowl. Her hair was splitting, and it had browned to the colour of moleskin because it had been straightened with red-hot iron combs. Wariinga also hated her teeth. They were a little stained; they were not as white as she would have liked them to be. She often tried to hide 
them, and she seldom laughed openly. If by mistake she laughed and then remembered her teeth, she would suddenly fall silent or else she would cover her lips with her hand. Men would sometimes tease her, calling her Wariinga, the angry one, because of her lips, which were always firmly pressed together.

But when Wariinga was happy and forgot to worry about the fading whiteness of her teeth and about the blackness of her skin and laughed with all her heart, her laughter completely disarmed people. Her voice was as smooth as perfume oil. Her eyes shone like stars in the night. Her body was a feast for the eyes. Often, when she walked along the road without self-consciousness, her breasts swaying jauntily like two ripe fruits in a breeze, Wariinga stopped men in their tracks.

But she would never appreciate the sheer splendour of her body. She yearned to change herself, in covetous pursuit of the beauty of other selves. Often she failed to dress in harmony with her body. She rushed to copy the ways in which other women dressed. Fashion, whether or not it flattered the shade of her skin or the shape of her figure, was what governed her choice of clothes. Sometimes, Wariinga distorted the way in which she held herself by trying to imitate another girl's stride. She forgot the saying: Aping others costs the frog its buttocks. (pp.11-12)

The modal activity here is illustrated through $\mathbf{0 2}$ generic or proverbial sentences; 03 similes (body like the guineafowl, eyes like stars at night, breasts like two ripe fruits in a breeze), 02 comparatives of equality, which are also similes (not as white as; as smooth as); 01 nominalised simile (i.e., the colour of the moleskin= as brown as a moleskin) and 01 metaphor (body = feast for the eyes); 05 modulators expressing inclination (would ....fall silent; would cover, would ...tease, would never appreciate, would have liked), and 04 modalisers expressing frequency (seldom, sometimes, often, never). It must be noted that in the first and third paragraphs of the quote above, the narrator depicts how the heroine sees herself in relation to others that she apes while in the second one; it is how she naturally appears that is exposed. The comment "in covetous pursuit of the beauty of other selves" and the two proverbs are enough to grasp the narrator's negative judgement on an attempt to see and change oneself by comparison with others. For reminder, the use of proverbial sentences, according to Fowler (1986), "makes the reader bound to suspect the objectivity of someone who is so self-conscious, so confident and considered in his judgements (p.137). The same applies for the negative images in paragraphs 1 and 3, and the positive ones in 2. The change in Wariinga's physical appearance as she stops comparing herself to others is clearly brought to light by the Devil, the Exploiter, the Liar, the Grabber, the Tempter, the Judge, in (22) below:

(22) "You have a young body. The joys of life are all before you. If you hadn't taken to singeing your hair with hot combs and your skin with lightening creams like Ambi, the sheer splendour of your body would have been pulling a thousand and one hearts behind it. The blackness of your skin is smoother and more tender than the most expensive perfume oils. Your eyes are brighter than the stars at night. Your cheeks are like two fruits riper than the blackberry. And your hair is so black and soft and smooth that all men must feel like sheltering from the sun in its shade" (p.192)

The third sentence of the quote, an if-clause $\mathrm{N}^{\circ} 3$, is enough to show the Devil's reproachful tenor to the young lady. Further modality is expressed through 04 comparatives of superiority (smoother than, more tender than, brighter than, riper than), 03 intensifiers (so black ...that, so soft ...that, so smooth that), and 01 simile (cheeks ... like two fruits). As can be seen, the reproachful tone set in the second sentence of quote (22) has yielded to one of admiration, praise and superiority, as the comparatives, the intensifiers and the metaphor, which act as modulators or strengtheners (McCornell-Ginet. et al., 1980; Coates, 1986), show Warīnga in a more positive light when she has stopped skinbleaching and dressing to please others or to look like them. This narratorial description of the heroine is much match with the Devil's as the critical tenor noticed in part of (22) has also become totally admirable in (23) below:

(23) Wariinga was dressed the Gikuyu way. A brown cloth, folded over a little at the top, had been passed under her left armpit, the two ends gathered together and held at the right shoulder by two flower-shaped safety pins, so that her left shoulder was bare. The cloth was long and fell to her ankles; its edges were held together on her right side by safety pins. Around her waist Wariinga had tied a knitted belt of white wool, the two long, loose ends of which fell the length of the cloth to her ankles. On her feet she wore leopard-like sandals. Around her neck were necklaces of white, red and blue beads, which sat beautifully on her breasts. She had Nyori-like earrings. Her hair was smooth, soft and black. As she walked, Wariinga appeared to be the child of Beauty, mother of all beauties, just created by the creator of the twins, elegance and beauty (p.242)

This is an over-praise of the beauty of a woman who has given up skin-bleaching and modern European clothes to keep to traditional dressing on her natural skin. Even though no comparison has been resorted to here as in earlier descriptions $(\mathbf{2 1}, \mathbf{2 2})$, phrases like "beads, which sat beautifully on her breasts," "the child of Beauty," "mother of all beauties," and "elegance and beauty" clearly show a description couched in highly hyperbolic terms. However, the 
modaliser/estranger 'appeared' leads the reader into thinking of an entirely external observer, the intensive process clause "Her hair was smooth, soft" -as opposed to "her hair looked smooth, soft" - does give the impression that the observer has been so close as to touch the hair being described. As it turns out, the observer here is Gatuiria, Waringa's fiancé. The reaction of other characters however gives a good degree of objectivity to both the narrator's and Gatuiria's description of the lady's beauty:

(24) 'And Gatuiria was not alone. Several passers-by stopped to watch Waringa. 'Oh, that's a fine-looking woman,' some said. Others commented: 'You see, there no tradition that can't be developed. Wherever she goes, people will deter to the beauty of that young woman!"' (p.243)

(25) "The guests left the room, glancing lasciviously at Waringa, some of them muttering to themselves: 'The young of today really are beautiful! What a terrible calamity old age is!"' (p.248)

Just as in (23) earlier, words like "lasciviously", and "deter to" in (25) are good indicators of the irrefutability of the beauty in question. Moreover, there is $\mathbf{0 1}$ modulator/strengthener "really" used in a marked position and $\mathbf{0 4}$ exclamatives "oh,!,!,!" that give greater authority to the comments being made.

The physical description of Wariinga's mother, a farming woman and Mau Mau detainee, reinforces the aboveportrayal of Warīnga as "the child of Beauty," and "mother of all beauties "(23), and is of one the most admirably given in the novel: (26) "She is elderly, but she is one of those people who never seem to age. Her white-and-black flowered frock, though a little faded, fits her well" (p.234). The observer's modality is expressed through the modal locution "never seem", which is actually demodalised to become modulated because of the effect of the strengthener "never" on the modaliser "seem." In addition, the narrator's resort to the simple present tense to describe this character gives her some agelessness or beauty and strength that defy the passage of time. The character most attractively/positively portrayed through other characters is Wangari, a woman farmer, and a former Mau Mau, who has got so much involved in the struggle that she has not had her ears pierced. In this section ([(p.196) 'Oh you should.... enough for me!' (p.199)], where Wangari's story is told by Gatuīria, a young intellectual and research fellow who has given up his father's wealth to study and compose music that tells the struggle story of the people, one can identify these comments, which are all in the exclamative mood to show the narrator's admiration/praise of the woman:

(27) "Oh, l've never come across a woman with so much courage! Wangari calmly walked up to the platform, and she silenced the whole cave with the power of her eyes -it was as if they were flames of fire-and then she denounced the thieves in a voice that did not betray the slightest trace of fear" (p.196).

(28) "It looked as if everyone in the cave had been transfixed by the electric power of Wangari's words. Oh Wangari was beautiful! I can tell you. Oh, yes. Wangari's face shone as she stood before us all and it looked as if her courage had stripped years from her body and given her a new life. It was as if the light in her face were illuminating the hearts of those present, and her voice carried the power and authority of a judge" (p.197).

(29) "And she was led out, still singing her defiance, her chained hands raised high above her head, the links gleaming like a necklace of courage. "Wangarī, heroine of our land!!" (p.198).

(30)" Gatuîria paused, as if Wangari’'s courageous voice were ringing in his ears. 'Wangarī, heroine of our land!' Gatuīria said again, slowly" (p.198).

The narrator Gatuiria's modal activity in these sequences is signalled by 08 exclamatives (oh, !, oh, !, oh, yes, !!, !); .05 modalisers or estrangers (it was as if, it looked as if, it looked as if, it was as if, as if), 02 of which are doubled (looked+ as if); 04 metaphors (eyes= flames of fire, voice=power and authority of a judge; words= electric power, voice= no fear), and 01 simile (chains ...like necklace of courage). However, it must be noted that the modalised comment (30) does not come from Gatuīria but from the main narrator. This narrator clearly agrees with Gatuīia's portrayal of Wangarī, as can be seen in this italicised comment on Wangarī's justification of her un-pierced ears:

(31) "I would rather put on earrings made of dry maize stems...the only problem is that I missed my chance to have my ears pierced....Because ours was not a time for adorning our bodies with flowers. Ours was a time for decorating ourselves with bullets in the fight for Kenya's freedom," Wangari said with pride, because she knew that the deeds of her youth had changed Kenya's history" (p.127).

The italicised sequence above clearly shows the narrator's positive attitude to the woman.

And Mūturi, the worker-delegate, quite clearly agrees with both Gatuĩria and the narrator as he proudly and happily exclaims:

(32)"But Muturi looked at Wangari, his heart overflowing with sudden pride and happiness: Wangari, heroine of our 
country! -all Wangaris, heroines of our land!" (p.127)

Here, too, one can notice the use of $\mathbf{0 2}$ exclamative marks (!), which puts the worker delegate in much the same tenor relationship with the young research fellow regarding Wangari. The description of the unnamed student leader cannot arouse some admiration from the reader:

(33) "He had a youthful build, though his face displayed maturity. He had a mass of jet-black hair and a beard like that of a small he-goat. His dark eyes shone with the light of a wisdom that sees many things hidden in the distance....He had on khaki jeans and a brown leather jacket. Under his left arm he carried a black leather bag" (p.14)

The description of the robbers' flight from the attacking masses is given with so many tenor clues that it cannot be viewed as ideologically neutral:

(34) "Any thief who managed to squeeze through would lumber across to his car like a hippo, and after a second, would raise dust as he speeded away, saying his prayers with all his soul.. Those who did not have fat bellies -the clan of the skinnies -would jump through the windows, and touching the ground, would dart away like arrows...But Wariinga was able to witness the wonderful spectacle of Gïtutu wa Gataangūrū and Nditika wa Ngūūnji, trying to run away, like two spiders with eggs, while their buttocks were lashed by their pursuers with sticks. By the time they reached their cars, they were panting and the sweat of pain and fatigue and fear fell to the ground in drops like rain during a heavy downpour. But when the foreign thieves were about to leave, their laughter turned into menacing roar. The people roared like a thousand angry lions whose cubs had been taken away from them.....After a while, not a single thief or robber was left in the area of the cave. All of them had managed to flee, as if they had suddenly grown wings of fear" 'pp.207-8)

The modal activity in this quote is marked by 05 similes (like, like, like, like, like). It must be noted in these comparisons that the thieves are likened to animals and things (hippos, pregnant spiders, arrows) and their sweating to a heavy downpour and are portrayed as being fearful, the people are assimilated with strength as they are shown as "a thousand angry lions." The fear-power contrast is strengthened by the estranger "as if" in the last sentence, which shows not only the externality of the observer but also subjectivity of his observation. The next section recapitulates the major findings of the research and attempts an interpretation for them.

\subsection{Recapitulation and Interpretation of the Findings.}

The table below summarises the findings. The first column gives the number of the quote, the second the compared entity, next the item it is compared with, and then the modal locutions used. In the last column entitled "authority", the symbol "+" shows that the modal locution expresses "modulation/authority/certainty/confidence" while "-" signals "modalisation/lack of authority/uncertainty/lack of confidence). It must be remarked that the heroine Wariinga's portrayal is divided into two phases: 'Wariinga 1' when she has been used to bleaching her skin and getting dressed to look like other people and 'Wariinga 2' when she becomes her own self. In the first stage, the narrator is found to adapt a critical tenor toward her while in the second one; this has yielded to more admirable, prideful, and praise-singing, even hyperbolic tenor.

Table 1: Recapitulation of Findings

\begin{tabular}{|c|c|c|c|c|}
\hline $\begin{array}{l}\text { Quote } \\
\mathrm{N}^{\circ}\end{array}$ & Character compared & Item/concept/image compared to/associated with & Modal locutions \& density & Authority \\
\hline 1 & Unnamed MC & melon, plum, baobab stem: disproportion & 04 similes (like, like, like, as) & "-" \\
\hline 2 & Foreign delegates & poleskin, pig, disfigured black person & 07 similes (07 'like'), 01 estranger (as if) & “-” \\
\hline 3 & The Devil & pig, two-mouthed ogre & 02 simile (02 'like') , 02 estrangers (02 'as if') & “-” \\
\hline 4 & European judge & pig, lizard & 02 similes (02 'like') & “-” \\
\hline 5 & The Devil & White European, monkey, pig & 04 similes (03 'like', 01 'as') & “-” \\
\hline 6 & $\begin{array}{l}\text { Ndaaya wa Karuria: a petty } \\
\text { thief/robber }\end{array}$ & His eyes $=$ electric bulbs & 03 similes (03 'like'), 02 estrangers (02 'as if') & “-” \\
\hline $7-8$ & Gitutu wa Gataanguru & rottenness, shit, disproportion, petrifaction & $\begin{array}{l}05 \text { estrangers (02 'seemed', } 03 \text { 'as if'), } 01 \\
\text { simile (01 'like') }\end{array}$ & “-” \\
\hline 9 & Kihaahu wa Gatheeca & Mosquito, mantis, mouth= beak of a kingstock & $\begin{array}{l}03 \text { similes (looked like, looked like, like), } 01 \\
\text { metaphor (head= cone) }\end{array}$ & “-” \\
\hline 10 & $\begin{array}{l}\text { Kĩmeedeeri wa Kanyuanjii, a } \\
\text { loyalist, a former District Officer }\end{array}$ & $\begin{array}{l}\text { eyes= two electric bulbs; head= tarmac road; pit } \\
\text { latrines, green blue flies, rotting rubbish }\end{array}$ & $\begin{array}{l}02 \text { estrangers (looked as if, as if): } 02 \text { similes } \\
\text { (looked like, as big as) }\end{array}$ & "-" \\
\hline
\end{tabular}




\begin{tabular}{|c|c|c|c|c|}
\hline $11-12$ & $\begin{array}{l}\text { Kĩmeedeeri wa Kanyuanjii, a } \\
\text { loyalist, a former District Officer }\end{array}$ & $\begin{array}{l}\text { mouth= ox-pecker's beak; } \\
\text { neck= skin of a hairy maggot; leg=giant banana } \\
\text { stem; leg= that elephantiasis sufferer, mouth = a } \\
\text { new born baby's }\end{array}$ & 05 similes (04 'like', 01 'as...as') & “-” \\
\hline 13 & Macura wa Kimeengemeenge & fat hog (=gros cochon) & 01 intensifier (so....that) & "+” \\
\hline 14 & Superintendent Gakono & fearful, corrupt & 02 estrangers (as if, as if) & "-" \\
\hline 15 & robbers/thieves/capitalists & fleas, jiggers, bedgugs, parasites & 04 metaphors, 01 estranger (as if) & “-” \\
\hline 16 & Githahi, a business tycoon & $\begin{array}{l}\text { jigger, louse, weevil, flea, bedbug, mistletoe, } \\
\text { parasite }\end{array}$ & 07 metaphors & "-" \\
\hline $17-19$ & Wariinga 2 & Judge, people's judge & 03 similes(like, like, like) & “-” \\
\hline 20 & Wariinga 1 & Guineafowl, moleskin & $\begin{array}{l}-02 \text { similes (like, like) } \\
-02 \text { generics }\end{array}$ & $\begin{array}{ll}\text { "-" } \\
\text { "+" }\end{array}$ \\
\hline 20 & Wariinga 2 & $\begin{array}{l}\text { body=perfume oil, body= feast for the eyes; } \\
\text { eyes= stars at night, breast= two ripe fruits }\end{array}$ & $\begin{array}{l}06 \text { similes (like, like, like, as, as, as); } 01 \\
\text { metaphor, }\end{array}$ & “-” \\
\hline 20 & robbers & $\begin{array}{l}\text { the fart of a badger, rotten beans, over-ripe } \\
\text { bananas, nausea' }\end{array}$ & $\begin{array}{l}-01 \text { negative modulator ( smelled worse than), } \\
01 \text { modaliser (as if), } \\
01 \text { simile (like) }\end{array}$ & \\
\hline 21 & Wariinga 1 & the silent one & $\begin{array}{l}-05 \text { modulators ('would') } \\
-04 \text { modalisers (frequency) }\end{array}$ & $\begin{array}{ll}-“+" \\
-“-" ”\end{array}$ \\
\hline 22 & Wariinga2 & $\begin{array}{l}\text { body }=\text { most expensive perfume oil, eyes= stars } \\
\text { at night, cheeks = two ripe fruits }\end{array}$ & $\begin{array}{l}04 \text { comparatives of superiority, } \\
03 \text { intensifiers, } \\
01 \text { simile (like) }\end{array}$ & $\begin{array}{l}-“+" \\
-"+", \\
-"-"\end{array}$ \\
\hline 23 & Wariinga 2 & $\begin{array}{l}\text {-child of Beauty, mother of beauties, elegance + } \\
\text { beauty }\end{array}$ & 01 estranger (appeared) & “-” \\
\hline $24-25$ & Wariinga 2 & -beauty & $\begin{array}{l}-04 \text { exclamatives } \\
-01 \text { modulator } \\
\end{array}$ & $\begin{array}{ll}-" 4+" \\
-“+"\end{array}$ \\
\hline 26 & $\begin{array}{l}\text { Wariinga's mother, a former } \\
\text { Mau Mau detainee }\end{array}$ & Beauty, agelessness & 01demodalised modaliser (never seem) & “+” \\
\hline $27-31$ & Wangari, a former Mau Mau & beauty, pride, courage, power, judge, heroine & $\begin{array}{l}-08 \text { exclamatives } \\
-05 \text { estrangers }+01 \\
\text { simile } \\
-04 \text { metaphors }\end{array}$ & $\begin{array}{l}-“+" \\
-"-" \\
-"+"\end{array}$ \\
\hline 32 & Wangari, & pride & -02 exclamatives & "+" \\
\hline 33 & Student-leader & Maturity, wisdom & & \\
\hline 34 & $\begin{array}{l}\text {-robbers } \\
\text {-the people }\end{array}$ & $\begin{array}{l}\text {-hippos, spiders with eggs, arrows } \\
\text {-a thousand angry lions }\end{array}$ & $\begin{array}{l}-04 \text { similes (like, like, like, like) } \\
+01 \text { estranger (as if) } \\
-01 \text { simile (like) }\end{array}$ & "-" \\
\hline
\end{tabular}

As can be seen from the table, there are about 95 locutions of modalisation (66.43\%) and 48 of modulation (33.57 \%) over a total of 143 indicators of modality identified. This means that the discourse is almost twice less authoritarian/confident/powerful than it is authoritarian/confident/powerful. This intensive use of modalisation can be accounted for by the fact that the main narrator is a subjective one that speaks in 'l', as opposed to an omniscient-one or a collective "we" one, as in Petals of Blood (1977) (Amoussou, 2011), and most of the descriptions analysed are narrated from the focalisation of individual characters, mainly Gatuîria and Wariinga. However, while most cases of modalisation (53/93:57\%) are found in the characterisation of capitalists, almost all cases of modulation (46/47: $98 \%)$ are found in that of proletarians. As modalisation is a mark of estrangement or exteriority, this percentage indicates that the narrators have marked their ideological distance from the robbers through the resort to this aspect of modality. Likewise, modulation is synonymous with confidence/objectivity/ authority, and its highest degree of use regarding proletarians certainly helps to mark the narrator's proximity and certainty about whatever is said about this group. Moreover, most of the modulated comments operate through the exclamative mood. It must be remembered that this mood is the one par excellence to express the emotional status of the speaker or writer in terms of bewilderment, surprise, disgust, concern, anxiety, happiness, admiration etc (Halliday, 1985; 2004; Eggins, 1994; Fowler, 1986). The intense use of this mood, on the positive pole, clearly shows not only the narrator's admirable portrayal of the characters concerned, but also his/her ideological siding with them.

\section{Conclusion}

Above all, it can well be contended that authority, through modality, and ideology have greatly influenced characterisation in this novel. Indeed, almost all loyalists, i.e., supporters of western imperialism and capitalism, are painted with animal imagery and the narratorial modality in their portrayal takes place almost exclusively through estrangers, indicators of exteriority to, or distance from, and uncertainty about what or who is depicted. On the other pole, the proletarians or 
patriots, who all have links with Mau Mau, are admirably painted in terms of positive concepts such as beauty, heroism, courage, wisdom, strength, power, authority, etc. The authoritarian modal activity, mainly through modulation and exclamation, is exclusively found in the portrayal of this group, which creates a closer and confident tenor between the narrators and these characters. However, the predominance of modalisation in the characterisation in this novel gives it a less aggressive and authoritarian tenor than Petals of Blood (1977), which is described as a 'bomb shell' (Amoussou, 2011). It must also be pointed out that the less authoritarian tenor is largely due to the choice of a subjective I-narrator and description of other characters through individual narrators who cannot but see and narrate the events from their personal, subjective point of view, without any pretension of omniscience

\section{References}

Amoussou, C. Y. (2014). "Transitivity Analysis of Two Stretches of Narrated Mental Discourse from Ngũgĩ's Wizard of the Crow," Revue du CAMES, 2 novembre 2014, Ouagadougou; pp.121-137.

Amoussou, C. Y. (2014). "Discourse Tenor, Context and Character in the Lawyer's Monster Parable (Petals of Blood); PARTICIP'ACTION, Volume6, N¹-janvier 2014 : Lomé (Togo); pp. 147-170.

Amoussou, C. Y. (2013). "Cultural, Ideological and Interpersonal Functions of Pronominalisation in Achebe's First Three Novels," Langage et Devenir N²3, Deuxième Semestre 2013, pp.207-222.-Amoussou, C. Y. (2011). "Characterisation, Focalisation and Discourse in Ngũgĩ wa Thiong'o's Novels: A Functional Structuralist Approach." Unpublished Ph. D-Dissertation, UAC.

Bloor T. \& Bloor M. (2004). The Functional Analysis of English (2nd ed). Britain: Hodder Education.

Brumfit, C.J. \& Carter, R.A. (1991): Literature and Language Teaching. Oxford: Oxford University Press.

Cummings, M. \& Simmons, R. (1983): The Language of Literature: A Stylistic Introduction to the Study of Literature. Oxford: Pergamon Press Ltd.

Dorsch, T. S. (ed.) (1965). Classical Literary Criticism. Harmondsworth: Penguin.

Eggins, S. (1994/2004). An Introduction to Systemic-Functional Linguistics. London: Pinter Publishers Ltd.

Fowler, R. (1986). Linguistic Criticism. Oxford: Oxford University Press.

Genette, G. (1980). Narrative Discourse. Ithaca, New York: Cornell University Press.

Giglioli, P.P (1972) (ed.). Language and Social Context. Harmondsworth: Penguin.

Halliday, M.A.K. (1970). 'Descriptive Linguistics in Literary Studies,' in Freeman, D. (1970): Linguistics and Literary Style. New-York: Holt, Rinehart and Winston, Inc.; pp. 57-71

Halliday, M. A. K. (1971). "Linguistic Function and Literary Style: An Inquiry into the Language of William Golding's The Inheritors," in Chatman S. (Ed) Literary Style. London: Oxford U.P.

Halliday, M. A. K. (1973). Explorations in the Functions of Language. London: Edward Arnold.

Halliday, M.A.K. (1978). Language as Social Semiotic: The Social Interpretation of Language and Meaning. London: Edward Arnold.

Halliday, M. A. K. (1985a). An Introduction to Functional Linguistics. London: Edward Arnold.

Halliday, M.A.K. \& Hasan, R. (1989). Language, Context and Text: Aspects of Language in a Social-Semiotic Perspective (2nd ed.) Oxford: Oxford University Press.

Halliday, M. A. K. \& Matthiessen (2004). An Introduction to Functional Grammar (3rd ed.) London: Hodder Headline Group.

Hill, C. (1987). "Leda and the Swan: Where Description Ends and Interpretation Begins," in The Penn Working Papers in Educational Linguistics 3 (1).

Jack, R. et al (1985). Dictionary of Applied Linguistics. UK: The Chancer Press Ltd.

Jakobson, R. (1960). 'Concluding Statements: Linguistics and Poetics,' in Sebeok, T. (ed.) (1960). Style in Language. Cambridge, MA: MIT Press.

Kariuki, J. M. (1963/75). Mau Mau Detainee. Nairobi: Oxford University Press.

Koussouhon, A. L. \& Amoussou, C. Y. (2013). "Functions and Contexts of Reference Deviation in Anthills of the Savannah," Safara $N^{\circ} 12$, janvier 2013, pp. 31- 52, Université Gaston Berger de St Louis, Sénégal.

Koussouhon, A. L. \& Amoussou, C. Y. (2007). "The Language of 'Abiku' (John Pepper Clark; Wole Soyinka): A Systemic Functional Analysis." Waves: An English-Language Journal. Nos 8-9 October 2006-2007. Université Omar Bongo, Libreville (Gabon) ; pp.251-281.

McCornell-Ginet, S. et al (eds) (1980). Women and Language in Literature and Society. New York: Praeger.

Ngara, E. (1982). Stylistic Criticism and the African Novel. London: Heinemann.

Ngũgĩ wa Th. (1981). Writers in Politics. London, Bedford, Ibadan, Nairobi: Heinemann Educational Books Ltd.

Ngũgĩ wa Th. (1977). Petals of Blood. London, Bedford, Ibadan, Nairobi: Heinemann Educational Books Ltd.

Ngũgĩ wa Th. (1982). Devil on the Cross. Heinemann: African Writers Series.

Pearce, R. (1977). Literary Texts: Discourse Analysis Monographs no 3. University of Birmingham: English Language Research.

Uspensky, B. (1970, trs 1973). A Poetics of Composition: The Structure of the Artistic Text and Typology of Compositional Form. Berkeley: University of California Press. 